\title{
Démon zrcadlem pravdy: Teologie, morální ponaučení a hereze v porýnském líčení exorcismu z okolí roku 1200
}

\author{
FRANTIŠEK NOVOTNÝ - DAVID ZBÍRAL
}

Kodex 9 z opatství svatých Petra a Pavla v belgickém Dendermonde (Termonde) obsahuje $\mathrm{z}$ převážné většiny literární a hudební díla benediktinské abatyše Hildegardy z Bingenu (1098-1179) a další benediktinské mystičky Alžběty ze Schönau, předních představitelek ženské porýnské mystiky vrcholného středověku. Na posledních foliích kodexu se nicméně dochoval jiný cenný text: líčení výslechu démona prováděného knězem během rituálu exorcismu, u něhož je přítomna právě abatyše Hildegarda. ${ }^{1}$

Latinsky psané líčení představuje morálně-edukativní text diskutující věroučná témata a otázky řádného života formou dialogu kněze a démona. Kněz se démona vyptává na různé druhy hřřšného nebo naopak ctnostného lidského jednání a démon potvrzuje, případně upřesňuje, jak hříchy lidí těší pekelné mocnosti a jak je lidské ctnosti naopak zraňují. Samotnou scénu exorcismu je třeba vnímat jako součást formy sdělení, jež textu dodávala na atraktivitě a potvrzovala závažnost témat, která otevírá.

Svým tematickým zaměřením se text blíží žánru exempel, krátkých příběhů s morálním ponaučením, obvykle obsahujících nadpřirozené prvky. Exempla, která původně představovala prvek k oživení kázání, se

1 Dendermonde (Belgie), Sint-Pieters- en Paulusabdij, ms. 9. Celý kodex s rozměry $19,7 \times 28,8$ cm sestává ze 173 pergamenových folií, na posledních šesti z nich $(170 \mathrm{v}-$ -173r) je zapsáno námi překládané líčení. Digitální reprodukce: „Dendermonde - SintPieters- en Paulusabdij - ms. 9“ [online], in: Teneo: Opslag en preservatie, <http:// depot.lias.be/delivery/DeliveryManagerServlet?dps_pid=IE9129581>, [7. 3. 2020]. Edice: Laurence Moulinier-Brogi, „Unterhaltungen mit dem Teufel: Eine französische Hildegard--Vita des 15. Jahrhunderts und ihre Quellen“, in: Alfred Haverkamp Alexander Reverchon (eds.), Hildegard von Bingen in ihrem historischen Umfeld, Internationaler wissenschaftlicher Kongreß zum 900jährigen Jubiläum, 13-19 September 1998, Bingen am Rhein, Mainz: Philipp von Zabern 2000, 519-560: 548-560. 
v průběhu 13. století vyprofilovala v samostatný literární žánr, sloužící nejen k edukaci laiků, ale i nižšího kléru a řeholníků. ${ }^{2}$ Text z kodexu 9 s exemply sbližují nejen témata, ale i jeho zarámování náznaky příběhu. Od typického exempla se nicméně liší jednak absencí narativní složky s rozuzlením v podobě jednotlivých morálních poučení, jednak tím, že na poměrně malém prostoru pokrývá širokou škálu témat dotýkajících se různých společenských vrstev. Tato témata sahají od zápovědi magických praktik přes odsouzení neřádného chování kněží a zavržení heretiků až k otázkám, jako je církevní exkomunikace. Na ploše pouhých šesti folií tak text odpovídá na otázky, které bychom jindy našli rozprostřeny v celé několikasetstránkové sbírce exempel.

Významnou charakteristikou textu je role démona neochotně potvrzujícího pravdy křestanské nauky a správného života. Toto potvrzení ústy nepřítele je ještě zesíleno zmínkami o podobách pekelných muk, jimiž jsou trestány konkrétní hříchy. V tom se líčení blíží žánru vidění pekelných hrůz. Zakládajícím textem tohoto žánru $\mathrm{v}$ křestanské tradici je Zjevení Pavlovo ze 3. století. $^{3}$ Ve vrcholném středověku se líčení hrůz pekla, případně útrap očistce, $\mathrm{z}$ nichž je vizionář nakonec vyveden $\mathrm{k}$ nazření nebeské blaženosti, těšila největší popularitě na Britských ostrovech. Můžeme jmenovat zejména Vidění Tnugdalovo, pocházející z poloviny 12. století, a o přibližně třicet let mladší Traktát o Očistci sv. Patrika. ${ }^{4}$ Ve světě elitní literatury tuto látku zpracoval na počátku 14. století Dante ve své slavné Božské komedii.

Text tedy kombinuje literární tradici vidění pekelných muk s řešením často konkrétních a praktických otázek, jimiž se zabývala církevní správa v oblastech dolního Porýní na konci 12. století (výslovně zmiňuje arcibiskupské město Mohuč coby dějiště katarských obřadů). Vrhá světlo nejen na to, jaké společenské jevy znepokojovaly představitele vrcholně středověké církevní správy, ale také na to, jakými způsoby byl démon coby literární

2 Pro přehled viz Claude Brémond - Jacques Le Goff - Jean-Claude Schmitt, L'Exemplum, (Typologie des sources du Moyen Âge occidental 40), Turnhout: Brepols ${ }^{2} 1996$; Hermann Bausinger, „Exemplum und Beispiel“, Hessische Blätter für Volkskunde 59, 1968, 31-43; Marie Anne Polo de Beaulieu - Jacques Berlioz, Les exempla médiévaux: Introduction à la recherche suivie des tables critiques de l'Index exemplorum de $F$. $C$. Tubach, Carcassonne: GARAE - Hésiode 1992; Teresa Szostek, Exemplum w polskim średniowieczu, Warszawa: Instytut Badań Literackich Polskiej Akademii Nauk 1997.

3 V českém překladu: Lenka Jiroušková (trans.), „Zjevení Pavlovo“, in: Jan A. Dus (ed.), Novozákonní apokryfy III: Proroctví a apokalypsy, Praha: Vyšehrad 2007, 275-305.

4 Pro české překlady viz Jana Zachová (trans.), „Tnugdalovo vidění“, in: Magdalena Moravová - Martin Nodl (eds.), Ráj, peklo a očistec ve středověkých viděních, (Memoria medii aevi 15), Praha: Argo 2011, 128-160; Josef Förster - Magdalena Moravová (trans.), „Očistec svatého Patrika - Vidění rytíře Oweina“, in: Magdalena Moravová - Martin Nodl (eds.), Ráj, peklo a očistec ve středověkých viděních, (Memoria medii aevi 15), Praha: Argo 2011, 179-199. 
postava využíván k prosazování církevní doktríny. Jak text prozrazuje, takové využití sahalo daleko za prosté „strašení peklem“. Démon zde vyzrazuje tajemství, projevuje drzost, vztek i strach a především je nakonec vždy přinucen bezvýhradně se podřídit Boží moci.

\section{Exorcismus ve stř̌edověkých pramenech}

Pramenů z doby od pozdní antiky do vrcholného středověku, které by se zabývaly praxí vymítání démonů z těl posedlých, je poměrně málo a jedná se vesměs o zmínky a úryvky, a to navzdory tomu, že má tento typ exorcismu kořeny už $\mathrm{v}$ novozákonních textech. Hovořilo-li se $\mathrm{v}$ raném a vrcholném středověku o exorcismu systematičtěji, téměř vždy se jednalo o křestní exorcismus, mající za cíl osvobození katechumena od vlivu zlých duchů. ${ }^{5}$ Klíčovým raně středověkým pramenem $\mathrm{k}$ exorcismu posedlých jsou rukopisy Římsko-germánského pontifikálu (Pontificale Romano-Germanicum), vlivné sbírky liturgických textů zkompilovaných v 10. století v Mohuči. ${ }^{6}$ Florence Chave-Mahirová ve své stěžejní práci o exorcismu posedlých ve středověku identifikovala tři manuskripty pocházející z Německa 12. století, navazující na rukopisnou tradici Ř́msko-germánského pontifikálu, které obsahují poměrně detailní exorcistické formule. ${ }^{7}$ Sama nicméně upozorňuje, že ani tyto manuskripty neposkytují téměř žádný vhled do toho, jak probíhal vrcholně středověký exorcismus coby rituál. Podotýká, že vlastně jediný typ vrcholně stř̌edověkých pramenů, který líčí tuto stránku exorcismu posedlých, jsou prameny hagiografické. ${ }^{8}$ Především se jedná o hagiografii Norberta $\mathrm{z}$ Xantenu, zakladatele rádu premonstrátů, a ovšem také Hildegardy z Bingenu. ${ }^{9}$ Do okruhu

5 Florence Chave-Mahir, „Medieval Exorcism: Hagiographical and Liturgical Sources“, in: Helen Gittos - Sarah M. Hamilton (eds.), Understanding Medieval Liturgy: Essays in Interpretation, London - New York: Routledge 2016, 159-176: 160.

6 Cyrille Vogel - Reinhard Elze (eds.), Le Pontifical romano-germanique du dixième siècle I-II, (Studi e testi 226-227), Città del Vaticano: Biblioteca Apostolica Vaticana 1963; F. Chave-Mahir, „Medieval Exorcism...“, 161-162.

7 Florence Chave-Mahir, L'exorcisme des possédés dans l'Église d'Occident $\left(X^{e}-X I V^{e}\right.$ siècle), Turnhout: Brepols 2011, 127-130; edice: ibid., 364-384. K tématu formalizace a propracovávání rituálů exorcismu v pozdější době, na přelomu středověku a raného novověku, viz Moshe Sluhovsky, Believe Not Every Spirit: Possession, Mysticism, and Discernment in Early Modern Catholicism, Chicago - London: The University of Chicago Press 2007.

8 F. Chave-Mahir, „Medieval Exorcism...“, 162.

9 Vita Norberti archiepiscopi Magdeburgensis (ed. Roger Williams): Georg H. Pertz et al. (eds.), Monumenta Germaniae historica: Scriptores XII, Hannover: Hahnsche Buchhandlung 1856, 670-703; Vita Sanctae Hildegardis: Jacques-Paul Migne (ed.), Patrologia Latina CXCVII, Paris: J.-P. Migne 1882, 91-130. 
pramenů dosvědčujících svatost této abatyše musíme započítat i náš text z kodexu 9.

Je otázkou, co lze z líčení exorcismů prováděných charismatickými postavami světců usuzovat o průběhu standardní liturgické praxe vymítání. Tato líčení mají za cíl vyzdvihnout mimořádnost darů, jimiž dotyčný světec disponoval, a to často v kontrastu s nesnázemi, do nichž se dostávají běžní představitelé církevní autority. Text, jehož překlad zde publikujeme, se navíc detailům vymítacího rituálu příliš nevěnuje. Několik z nich nesouvisle představuje, např́iklad důležitost kněžské štóly při exorcismu, téma navazující na tradici hagiografie Norberta z Xantenu, ${ }^{10}$ daleko více se ale věnuje výslechu démona o věroučných a mravoučných otázkách a právě zde spočívá jeho hlavní přínos.

\section{Témata}

Jednoduchá forma textu vyhovuje jeho morálně-edukativnímu poslání. Hned v úvodu vyzdvihuje moc nejvyšší z církevních svátostí, tedy eucharistie, a oporu, kterou Boží tělo skýtá věřícímu v boji s dáblovými úklady. Tento úryvek lze považovat za formální uvedení celého textu, jelikož je svátosti věnována vlastně jen úvodní věta a teologické nauky kolem eucharistie nejsou dále diskutovány. Především se zde nijak neodráží diskuse kolem transsubstanciační doktríny, která byla přijata na Čtvrtém lateránském koncilu (1215). Tato okolnost se zároveň zdá hovořit pro redakci textu před rokem 1215 spíše než po roce 1230, jak se domnívá Uwe Brunn a jak bude diskutováno dále. Ve prospěch redakce po roce 1215 se naopak zdá svědčit pasáž o důležitosti další svátosti, zpovědi. Text totiž zdůrazňuje nejen její dokonalou účinnost v boji s d'áblem, kdy se ani démoni nedokáží rozpomenout na hříchy lidí, kteří se vyzpovídali, ale také nutnost zpovídat se knězi vlastní farnosti. To se zdá př́imo navazovat na 21. kánon Čtvrtého lateránského koncilu, nařizující laikům zpovídat se aspoň jednou $\mathrm{v}$ roce právě knězi vlastní farnosti. Je nicméně otázkou, zdali kánon koncilu skutečně představoval zásadní novinku, či jen potvrdil už probíhající trend centralizace církevní správy, jak soudí Alexander Murray. ${ }^{11}$ Otázka časové souslednosti redakce rukopisu a Čtvrtého lateránského koncilu zůstává v tomto ohledu nerozhodnutelná.

Ze svátostí se dále zdůrazňuje nezbytnost křtu pro spásu. Text potvrzuje i nerozlučitelnost manželství, nezmiňuje ale explicitně jeho svátostný status - pojetí manželství coby jedné ze sedmi svátostí se na přelomu 12.

10 Vita Norberti archiepiscopi Magdeburgensis: G. H. Pertz et al. (eds.), Monumenta Germaniae historica: Scriptores XII..., 680.

11 Alexander Murray, „Confession before 1215“, Transactions of the Royal Historical Society 3, 1993, 51-81: 64. 
a 13. století teprve ustavovalo. Vủbec poprvé se objevilo na koncilu ve Veroně roku $1184 \mathrm{v}$ rámci polemiky s protisvětskými názory určitých křestanských skupin odsouzených coby heretických a označovaných svými odpůrci jménem kataři. Prohlášení manželství za svátost tehdy zdůrazňovalo pozitivní význam manželství pro spásu v kontrastu s katarskými učeními o hř́šnosti všech forem sexuality. ${ }^{12}$

Také v našem textu z kodexu 9 hraje důležitou roli téma hereze katarů. Samotné označení „kataři““ má svůj původ právě v Porýní, konkrétně v díle benediktinského opata Ekberta ze Schönau, který mezi lety 1163 a $1165^{13}$ sestavil svou Knihu proti katarským bludiom (Liber contra hereses katharorum) ${ }^{14}$ Do boje proti katarské herezi se zapojila i sama abatyše Hildegarda z Bingenu, ${ }^{15}$ a není proto nijak překvapivé, že se mu věnuje i náš rukopis. Ten vykresluje katary hned ve dvou od sebe oddělených pasážích coby účastníky kultu dábla, páchající obscénní orgie a usmrcující $\mathrm{z}$ nich počaté děti. $\mathrm{V}$ mnoha ohledech navazuje na protikacírské stereotypy o obscénních kultech, které mají kořeny u křestanských autorů pozdní antiky, především u Augustina, a na středověkém Západě byly oživeny kronikáři 11. století (Adémar z Chabannes, Pavel z Chartres), respektive počátku století 12. (Guibert z Nogentu). ${ }^{16}$ Samotné označení katarů je v rukopise z kodexu 9 vysvětleno jako odvozenina od latinského slova pro kočku (cattus), nebot, jak démon v textu prozrazuje, právě v podobě kočky,

12 Pro přehled viz Francis Schüssler Fiorenza - John P. Galvin (eds.), Systematic Theology, Minneapolis: Fortress Press 1991, 319-320.

13 Uwe Brunn, Des contestataires aux „,cathares“: Discours de réforme et propagande antihérétique dans les pays du Rhin et de la Meuse avant l'Inquisition, (Collection des Études Augustiniennes: Moyen Âge et Temps Modernes 41), Paris: Institut d'études augustiniennes 2006, 218-219.

14 Uwe Brunn, „Cathari, catharistae et cataphrygae, ancêtres des cathares du XIIe siècle?“, Heresis 36-37, 2002, 183-200; id., Des contestataires aux „,cathares “..., 315342; David Zbíral, Největši hereze: Dualismus, učenecká vyprávění o katarství a budování křestanské Evropy, (Každodenní život 37), Praha: Argo 2007, 13-30.

15 Raoul Manselli, ,Amicizia spirituale ed azione pastorale nella Germania del sec. XII: Ildegarde di Bingen, Elisabetta ed Ecberto di Schönau contro l'eresia catara“, Studi in onore di Alberto Pincherle: Studi e materiali di storia delle religioni 38, 1967, 302313; Margarethe Profunser, Hildegard von Bingen und Bernhard von Clairvaux im Kampf gegen den Katharismus [rukopis diplomové práce], Innsbruck: LeopoldFranzens-Universität Innsbruck 1995; Beverly Mayne Kienzle, „Operatrix in vinea Domini: Hildegard of Bingen's Preaching and Polemics against the Cathars“, Heresis 26-27, 1996, 43-56; ead., „Defending the Lord's Vineyard: Hildegard of Bingen's Preaching against the Cathars", in: Carolyn Muessig (ed.), Medieval Monastic Preaching, Leiden - Boston - Köln: Brill 1998, 163-181; ead., „L'exégèse d'Hildegarde et sa prédication contre l'hérésie“, in: Écrire l'histoire d'une hérésie, Mazamet: Association de Valorisation du Patrimoine Mazamétain 2008, 26-47.

16 Martin Bouquet et al. (eds.), Recueil des historiens des Gaules et de la France X, Paris: Victor Palmé 1874, 159; Jacques Paul Migne (ed.), Patrologia Latina CLV, Paris: J.-P. Migne 1855, 265-266; id. (ed.), Patrologia Latina CLVI, Paris: J.-P. Migne 1880, 951. 
„nejšpinavějšího zvířete“, se katarům zjevuje d’ábel a nechává se od nich líbat na pozadí. Tato etymologie slova katar se nevyskytuje v Ekbertově Knize proti katarským bludům, která se přiklání ke standardnímu odvozování jména $\mathrm{z}$ řeckého katharos (čistý), ${ }^{17}$ ale je doložena - vedle dalších dvou - u významného teologa pozdního 12. století Alana z Lille. ${ }^{18}$ Bizarní popis d’ábelské kočky v našem textu, která je „velká jako velký pes a z obou boků jí vyráží ptačí peří a barvu má bílou“, připomíná karikaturu ikonografie andělů a nejspíš odkazuje k evangelijnímu výroku o dáblu přestrojujícím se za anděla světla $(2$ Kor 11,14$)$ : právě za „,dobrého anděla“ mají podle textu někteří heretici podivuhodnou kočku považovat. Zásadní charakteristikou líčení katarské sekty v překládaném textu je, že se v něm neobjevuje žádná zmínka o křtu vkládáním rukou, takzvaném consolamentu, který představuje konstitutivní rys katarství tak, jak ho popisovali hereziologové 13. století. Zdá se, že autorovi příslušných pasáží nebyl tento rituál znám, což opět hovoří pro poměrně raný vznik textu, předcházející období, kdy se povědomí o consolamentu, praktikovaném v některých heterodoxních skupinách Languedoku a Lombardie, rozšířilo na sever.

Ve stručných, ale velmi cenných pasážích se text obrací k zápovědi čarování a pověr. $Z$ takto poměrně rané doby se dochovalo jen málo vhledů do světa problematických lidových věr a praktik. Text zapovídá věštění z pohybu zvířat (aneganc), propichování voskových figurek s cílem ublížit osobě, již figurka představuje, stejně jako víru ve skřítky či permoníky (Witdechen), kteří mají obdarovávat lidi poklady, a v postavu jménem Holda, která se má lidem zjevovat v podobě vznešené paní. Permoníci i Holda jsou, jak démon prozrazuje, ve skutečnosti jeho druhové.

Zmínka o Holdě si zaslouží značnou pozornost, stejně jako skutečnost, že se její jméno v textu vyskytuje v těsném sousedství zmínky o permonících. Holda se poprvé objevuje v několika rukopisech sbírky kanonického práva sestavené na počátku 11. století biskupem Burchardem z Wormsu a známé jako Decretum Burchardi. ${ }^{19}$ Burchard do ní začlenil pasáž z tak zvaného Canonu Episcopi, pastorálního spisu pocházejícího patrně z přelomu 9. a 10. století. $^{20}$ Pasáž zapovídá víru jistých žen, které tvrdí, že v noci létají vzduchem v družině římské bohyně Diany, coby d'ábelské mámení. Burchardova sbírka doplňuje Dianu v závislosti na konkrétním

17 Jacques-Paul Migne (ed.), Patrologia Latina CXCV, Paris: J.-P. Migne 1855, col. 31.

18 Jacques-Paul Migne (ed.), Patrologia Latina CCX, Paris: J.-P. Migne 1864, col. 366.

19 Burchardus Wormatiensis, Decretum 10.1.: Jacques-Paul Migne (ed.), Patrologia Latina CXL, Paris: J.-P. Migne 1853, 833.

20 Nejstarší známá verze textu je zahrnuta ve spisu Libri de synodalibus causis et disciplinis ecclesiasticis, sestaveném benediktinským opatem Reginem z Prümu na počátku 10. století. Viz Regino Prumiensis, Libri de synodalibus causis et disciplinis ecclesiasticis II. CCCLXIV: Jacques-Paul Migne (ed.), Patrologia Latina CXXXII, Paris: J.-P. Migne 1880, 352. 
rukopisu bud' o jméno Herodiady, zlovolné matky biblické Salome, nebo právě o jméno Holdy. V další přejímce téže pasáže, která se objevuje v autoritativní sbírce církevního práva sepsané kolem roku 1140 v Bologni a známé jako Decretum Gratiani, je zachována varianta s Herodiadou. ${ }^{21}$ Lze předpokládat, že Holda byla populární mytologickou postavou v určitých částech německy mluvících zemí a jako taková byla známá bud' přímo wormskému biskupovi, nebo některým opisovačům jeho díla; ne už tak italskému autorovi Decreta Gratiani. Konkrétní charakteristiky Holdy je mimořádně obtížné rekonstruovat. Etymologicky snad může být její jméno příbuzné s Huldrami, člověku nebezpečnými obyvatelkami hor ze skandinávského folkloru. ${ }^{22}$ Holda je každopádně zmiňována v pozdně stř̌edověké a raně novověké německé literatuře jako vládkyně podzemních síní plných hojnosti, nacházejících se v útrobách jakési hory. ${ }^{23}$ Tento motiv, zpracovaný Richardem Wagnerem v prvním dějství slavné opery Tannhäuser, pojednávajícím o návštěvě „Venušiny hory“, lze zpětně dobře sledovat do první poloviny 15 . století k dílu La Salade francouzského dvořana Antoina de La Sale, který pojednává o hoře „královny Sibyly“ kdesi ve střední Itálii, ${ }^{24}$ a také ke zmínce dominikánského teologa Jana Nidera o lidech, kteří se snaží najít sídlo „Venuše“ uvnitř jisté hory. ${ }^{25}$ Východiskem pro studium tohoto motivu se stala klasická práce Philipa Barta z roku 1916, hledající kořeny motivu $\mathrm{v}$ estetice vrcholně středověkých rytířských romancí, především ve verzi příběhu o Parsifalovi a svatém grálu od Wolframa z Eschenbachu. ${ }^{26}$ Bezprostřední juxtapozice zápovědi víry v Holdu a v ,„permoníky“ obdarovávající lidi poklady významně naznačuje, že spojení vznešeně působící ženské postavy jménem Holda s podzemními síněmi hojnosti sahá přinejmenším do 12 . století. Především pak

21 Decretum Gratiani II, 26.5.12: Emil Friedberg (ed.), Decretum magistri Gratiani [online], Leipzig 1879, <https://geschichte.digitale-sammlungen.de//decretum-gratiani// text/>, [20. 1. 2021].

22 Viz Katherine Mary Briggs, The Fairies in English Tradition and Literature, London: University of Chicago Press 1967, 147.

23 Viz klasický přehled Sabine Baring-Gould, Curious Myths of the Middle Ages, London: Rivington's 1877, 209-229. Baring-Gouldová interpretuje tento motiv v tradici bádání konce 19. století jako pokřestanštěnou verzi univerzálního evropského mýtu zachyceného už Homérem v příbězích o nymfě Kalypsó a čarodějce Kirké, snažících se svými kouzly omámit a pro sebe získat hrdinu Odyssea (ibid., 228). Ačkoliv těžko nalezneme důkazy, které by takto zformulovanou hypotézu podpořily tváří v tvář kritickému zkoumání, motivy proradně vábivých ženských postav ve středověké mýtotvorbě stále představují relevantní téma, mimo jiné ve vztahu k tématům křestanské démonologie.

24 Gaston Paris, Légendes du Moyen Âge, Paris: Hachette 1903, 67-109.

25 Johannes Nider, Praeceptorium Divinae legis sive expositio decalogi, Nürnberg: Anton Koberger 1496, I.XI.3, fol. 43v.

26 Philip Barto, Tannhäuser and the Mountain of Venus, Oxford - New York: Oxford University Press 1916, zejm. 3-17. 
představuje, vedle mnohem mladší zmínky v díle Jana Nidera, další indicii, že se nejednalo toliko o elitní literární motiv, nýbrž o fenomén se silným folklorním rozměrem.

Poměrně raritním tématem, jemuž se text věnuje, je problematika zástupných pokání za duše v očistci (zde pojmenováno slovem carina, označujícím čtyřicetidenní kajícný půst). Nejednalo se o snahu ukrátit soužení dotyčné duše skrze modlitby a mše provedené kněžími a řeholníky, nýbrž o kajícnické praktiky vykonané typicky příbuzným nebožtíka, o němž se soudilo, že si v očistci odpykává zvlášt těžký trest za hříchy, za něž se nestačil kát na zemi. Tato sporadicky zdokumentovaná praxe se konceptuálně blíží dobrovolnému pokání za hříšný svět, které se, jak si všiml Gavin Fort, objevuje v řadě hagiografických pramenů ze 13. století pojednávajících o životě zbožných žen z dnešní střední a východní Belgie - území navázaného na porýnská města skrze jurisdikce kolínského a trevírského arcibiskupství. ${ }^{27}$ To nastoluje otázku, nakolik se mohlo jednat o součást širšího fenoménu typického pro vrcholně středověké dolní Porýní, respektive přilehlé nížiny na západ od něj.

Celým textem čtenáře provázejí líčení pekelných muk. Ta jsou, jak bylo zmíněno výše, rozepsána $\mathrm{v}$ duchu literární tradice vidění pekla. Za povšimnutí zde stojí poznámka o „Luciferově chřtánu“, odkazující k rozšířenému ikonografickému motivu pekelné tlamy požírající hříšníky. Svou ikonografickou paralelu má také motiv hříšných duší nadnášených vzhůru uprostřed ohnivého sloupce a následně dopadajících zpět do žhavých hlubin. Ohnivá muka se v pekle střídají s trýzněním mrazem - nikoliv nepodobně kontrastu žhavých a mrazivých pekel, zcela nezávisle se objevujícímu v buddhistické ikonografii. ${ }^{28}$ Tato paralela jen potvrzuje, jak jsou líčení posmrtných útrap např́č kulturami antropologicky konstantní a pracují s bezprostředními smyslovými zkušenostmi bolesti a nepohodlí. Celý text pak ilustruje, jak účinně může připomínání těchto univerzálních zkušeností sloužit $\mathrm{k}$ výchově jedince i k upevňování společenského řádu.

\section{Datace}

O dataci rukopisu, v němž se text zachoval, nelze říct mnoho. Je zřejmé, že byl sepsán někdy v druhé polovině 12 . nebo první polovině 13. století. Písařská ruka, která jej zapsala, je v rámci celého kodexu unikátní - do-

27 Gavin Fort, „Suffering Another's Sin: Proxy Penance in the Thirteen Century“, Journal of Medieval History 44/2, 2018, 202-230.

28 V češtině viz zejm. Dan Berounský, ,Vrány rozsévající děs a červi s železnou tlamičkou: Pekla v tibetském textu abhidharmy“, Religio: Revue pro religionistiku 15/1, 2007, 109-124; Luboš Bělka, „Buddhistická pekla: Zobrazení a texty vztahující se k třetímu peklu Sangháta“, Religio: Revue pro religionistiku 17/2, 2009, 231-249. 
tyčný písař zapsal téměř jistě pouze text o exorcismu, žádné jiné texty v kodexu obsažené, a doplnil jej na několik posledních folií. To hovoří pro možnost pozdějšího doplňku do už existujícího kodexu. Text zároveň začíná na témž foliu, na němž končí předchozí dílo. To vylučuje možnost, že by byla do kodexu pouze vevázána další folia: líčení exorcismu bylo koncipováno jako součást celé obsáhlé kompilace, bud' vznikající, nebo už nějakou dobu existující. K přesnějšímu určení okolností vzniku rukopisu by bylo třeba podrobné kodikologické analýzy, především co se týče materiálu a technologie vazby kodexu.

Ohledně redakce textu existují dvě hypotézy. Laurence Moulinier-Brogiová soudí, že byl text sepsán ještě za života Hildegardy z Bingenu. Svou argumentaci opírá o použitý titul Hildegardy coby „naší paní“ (domina nostra), který, jak soudí, nejspíš použil autor z řad ctitelů a následovníků stále žijící abatyše. ${ }^{29}$ To nepovažujeme za přesvědčivou argumentaci. Okamžitě po Hildegardině smrti začaly totiž o mystičce vznikat hagiografické texty a titul „,naše paní“ lze bez obtíží pokládat za součást standardního hagiografického výraziva.

Na nepř́iliš velkou přesvědčivost argumentace Moulinier-Brogiové poukázal Uwe Brunn, který zároveň představil vlastní hypotézu, datující redakci textu o více než půlstoletí později, do doby působení inkvizitora Konráda z Marburgu v mohučské arcidiecézi na počátku třicátých let 13. století. ${ }^{30}$ Soudí, že text, který se hned na dvou místech zabývá katarskou herezí, vznikl, nebo byl přinejmenším nově redigován na podporu inkvizitorovy aktivity. Brunn svou dataci opírá o tři argumenty. Nejpádnější z nich se týká blízké paralely mezi naším textem z kodexu 9 a dalším líčením exorcismu, objevujícím se v legendě o porýnském opatovi Ekbertovi ze Schönau, sepsané během poslední dekády 12. století. Brunn soudí, že tato legenda text z kodexu 9 předchází, případně že oba texty vznikly ve stejné době, a vylučuje tedy dataci před rok $1190 .{ }^{31}$ I pokud však na tuto argumentaci prristoupíme, nic stále neukazuje na Brunnem navrhovanou pozdní dataci do třicátých let 13 . století.

Brunn dále upozorňuje na několik v textu obsažených motivů, které nejsou z dvanáctého století známy, zato se však objevují v exemplech ze století třináctého, počínaje Vyprávěním o zázracích porýnského cisterciáka Caesaria z Heisterbachu (kolem 1220). Jde zejména o motiv démona sedícího na vlečce šlechtičny nebo démona zapisujícího hříchy lidí do knihy. Tento argument je nicméně velmi spekulativní. Literatura exempel z logiky své populárně-edukativní funkce pracovala se známými motivy

29 L. Moulinier-Brogi, „Unterhaltungen mit dem Teufel...“, 533.

30 U. Brunn, Des contestataires aux „,cathares “..., 487.

31 Ibid., 487-495. 
přítomnými v orální kultuře. Že redaktor textu pracoval s Caesariovými exemply, není o nic pravděpodobnější, než že použil motivy z obecné populární imaginace o pár let či desetiletí před Caesariem. Nakonec se Brunn opírá o specifický motiv významu kněžské štóly pro úspěšné provedení exorcismu. Brunn soudí, že se poprvé objevuje právě v textu z kodexu 9. Ve skutečnosti se však objevuje už v polovině 12. století v hagiografii zakladatele premonstrátského řádu Norberta z Xantenu. ${ }^{32}$ Brunnova argumentace raným výskytem dílčích motivů tedy ve skutečnosti mnoho nedokládá.

Pádným argumentem proti Brunnově dataci je naopak samotné vylíčení katarské sekty, které Brunna vedlo ke spojení textu s inkvizitorem Konrádem z Marburgu. Přri srovnání způsobu, jakým jsou kataři v textu představeni, a obrazu dábelské sekty z prostředí Konráda z Marburgu, o němž podává zprávu především bula papeže Řehoře IX. Vox in Rama z června 1233, nacházíme velmi málo společných motivů. V textu o exorcismu především chybí narážky na víru kacířủ v dobytí nebes Luciferem, které ve Vox in Rama tvoří klíčový prvek údajné heretické věrouky. ${ }^{33}$ Vox in Rama zase neobsahuje motiv usmrcování dětí s následným pálením mrtvolek a vyráběním kouzelného prášku, což je motiv, který rezonuje v pramenech 11. a počátku 12 . století. ${ }^{34}$ Souhrnně řečeno text o exorcismu představuje obraz dábelské hereze, který se zásadně liší od obrazů vzešlých z okruhu Konráda z Marburgu, a dotyčné pasáže hovoří spíše proti hypotéze o redakci textu v Konrádově době než na její podporu.

Zdá se, že rozhodující redakce textu pracovala s démonizovaným obrazem katarské hereze blízkým jeho původní porýnské podobě, známé z díla Ekberta ze Schönau, předtím, než do sebe tyto obrazy integrovaly rituál consolamenta či languedocké a lombardské představy zahrnované pod pojem vyhraněného metafyzického dualismu. Zmínka o pekelných trestech prripravených pro obhájce a podporovatele katarů (s. $70 \mathrm{v}$ tomto článku) může naznačovat, že text byl redigován po vydání buly Lucia III. Ad Abolendam z roku 1184, která etablovala tresty pro podporovatele heretiků do církevního práva. ${ }^{35}$ Týmž dechem je třeba dodat, že toto téma bylo v kuriálních kruzích řešeno delší dobu, jak o tom svědčí 27. kánon Třetího

32 Vita Norberti archiepiscopi Magdeburgensis: G. H. Pertz et al. (eds.), Monumenta Germaniae historica: Scriptores XII..., 680.

33 Bernd-Ulrich Hergemöller (ed.), Krötenkuss und Schwarzer Kater: Ketzerei, Götzendienst und Unzucht in der inquisitorischen Phantasie des 13. Jahrhuderts, Warendorf: Fahlbusch 1996, 25-32.

34 Typicky kronikářský záznam Adémara z Chabannes o herezi jistých řeholních kanovníků v Orléans roku 1022. Viz M. Bouquet et al. (eds.), Recueil des historiens des Gaules et de la France X..., 159.

35 Viz James Fearns (ed.), Ketzer und Ketzerbekämpfung im Hochmittelalter, Göttingen: Vandenhoeck und Ruprecht 1968, 61-63. 
lateránského koncilu z roku $1179,{ }^{36}$ a jeho reflexe v rukopise nemusí být vázána na konkrétní dokument.

Pozornost, která je tématu katarské sekty věnována, zároveň činí nepravděpodobnou redakci textu přibližně mezi lety 1200 a 1230, kdy se zprávy o katarech z dolního Porýní odmlčují. Můžeme tedy usuzovat, že klíčová redakce textu proběhla $\mathrm{v}$ závěru 12 . století, tedy zhruba $\mathrm{v}$ době, kdy se u Alana z Lille objevuje etymologie jména „kataři“ ze slova cattus, která je spojnicí s naším textem. Dataci ranější než do doby Konráda z Marburgu nasvědčuje i absence jakékoliv zmínky o žebravých řádech, které se rozšiřilly do Porýní ve dvacátých letech 13. století. Toho si všímá i Uwe Brunn, když upozorňuje, že text rozděluje řeholníky na černé (tradiční benediktiny) a šedé (reformované řády, především cisterciáky, případně členy Tironské kongregace), nikoliv na mnichy ve vlastním slova smyslu a mendikanty. Brunn se domnívá, že se jedná o pozůstatek některé ze starších redakčních vrstev, z nichž text vycházel. ${ }^{37}$ Oprostíme-li se od neopodstatněného datování bud' před rok 1180 , anebo po roce 1230 , tato okolnost nejvíce ze všeho podporuje hypotézu, podle které text spadá do okruhu raných hagiografií Hildegardy z Bingenu a k jeho rozhodující redakci došlo někdy v poslední dekádě 12 . století.

\section{Kompozice}

Zde přeložený text nepochybně závisí na starší předloze či předlohách. Absence jakéhokoliv uvedení do situace, postupně se zestručňující forma vyjadřování i jakoby nesouvisle vložená pasáž, v níž vystupuje Hildegarda z Bingenu a v níž se objevuje zmínka o ,démonovi v další ženě“, s jistotou prokazují, že rukopis je bud' kompilátem výňatků z několika předloh, anebo zestručněnou verzí jediné rozsáhlejší předlohy. Rozhodnout mezi těmito dvěma možnostmi není snadné. Pro hypotézu o kompilátu z vícera předloh se zdá svědčit velká tematická různorodost otázek, jež kněz démonovi klade, ${ }^{38}$ ve skutečnosti však tato různost otázek kompilativní charakter textu neprokazuje: dost dobře mohl existovat soupis otázek a odpovědí týkajících se různých témat katolické víry a etiky, zarámovaný dramatickou scénou exorcismu. Ani právě zmíněný náhlý vstup Hildegardy z Bingenu do dialogu kněze a démona nemusí představovat šev mezi různými texty, ale naopak pozůstatek původní narativní složky líčení, která byla $\mathrm{z}$ naší zestručněné verze $\mathrm{z}$ větší části vypuštěna, zatímco zachována zůstala téměř výhradně série otázek a odpovědí. Pro hypotézu o zestručněné

36 Ibid., 60-61.

37 Uwe Brunn, Des contestataires aux „,cathares “..., 495.

38 Uwe Brunn rovněž soudí, že původní text byl v několika vrstvách obohacen; viz ibid. 
verzi hovoří zachovaná forma dialogu, jehož zápis se vyvíjí směrem k větší strohosti: slovo ,sacerdos“ (kněz) je nahrazeno písmenem „S“; postupně mizí i líčení interakce mezi knězem a démonem a text se mění v prostý soupis otázek a odpovědí. To pravděpodobně naznačuje, že písař pracoval s rozsáhlou a podrobnou předlohou, kterou v průběhu opisování čím dál více redukoval. Jedinou výjimku z tohoto trendu představuje moment, kdy na scénu vstupuje Hildegarda z Bingenu. Kopista, který vzhledem k rukopisnému kontextu zjevně náležel k okruhu Hildegardiných obdivovatelů, zřejmě chtěl vyzdvihnout abatyšinu roli, a zachoval tedy zmínku o ní.

Na druhou stranu text vykazuje kompoziční zlomy, kde na sebe témata nenavazují organicky. Např́iklad problematika katarské hereze je řešena na dvou různých místech, přičemž v první pasáži démon nedořekne, co všechno mají kataři „,společného s kočkou“, zatímco druhá pasáž začíná otázkou: „Na jaké místo líbají kataři kočku?“ Zdá se tedy, že písař pracoval se dvěma odlišnými předlohami líčícími katary jako uctívače kočky, nebo s jedinou předlohou, kterou rozdělil a mezi její jednotlivé části začlenil další pasáže. Pro druhou hypotézu svědčí dvě zmínky o údajném katarském lámání vazů nemluvňátkům na stranách 71 a 78 tohoto textu, u nichž se zdá pravděpodobné, že na sebe v předloze navazovaly.

Jako nejpravděpodobnější se jeví, že písař pracoval primárně s jednou rozsáhlou předlohou, kterou zestručnil, některá dílčí témata do ní ale zároveň doplnil z jiných zdrojů, snad navázaných na okruh raných hagiografií Hildegardy z Bingenu. Ty ostatně představují abatyši mimo jiné coby exorcistku, jež od vymítaného démona zjistila „mnohé o zatracení katarü“39

\section{Prvky vernakulárního jazyka}

V textu se objevuje několik německých slov, které potvrzují geografickou oblast vzniku rukopisu. Jedná se vesměs o názvy konkrétních bytostí, jež neměly vůbec žádný nebo žádný běžně uživaný latinský ekvivalent: Paní Holda, permoníci (Witdechen), démoni Suslufult, Snelhart a Nochdols. Objevují se také německé výrazy pro bubny (trumma) a pro vlečku dámských šatů (volgenir). V druhém případě je použití vernakulárního jazyka předem uvozeno (,věc, které se lidově říká ..."). Autor předlohy si patrně bud' nebyl jist latinským výrazem pro vlečku, nebo pochyboval, že takové slovo budou znát čtenáři jeho spisu. Pro první možnost hovoří opis pojmu „pýcha“ slovním spojením „vysoká mysl“" (alta mens), které je očividně otrockým překladem německého slova Hochmut do latiny a naznačuje, že přinejmenším v jisté fázi redakce text zpracovával autor, který místy pře-

39 Vita sanctae Hildegardis: J.-P. Migne (ed.), Patrologia Latina CXCVII..., col. 126. 
mýšlel spíše v němčině. Otevřená zůstává otázka, zda se ve starší rukopisné tradici textu mohlo objevovat více německého výraziva, které bylo v průběhu opisování z větší části latinizováno.

\section{Překladatelská poznámka}

Český překlad vychází z edice Laurence Moulinier-Brogiové ${ }^{40} \mathrm{~s}$ přihlédnutím $\mathrm{k}$ digitální reprodukci rukopisu. Text překládáme $\mathrm{v}$ úplnosti. Zachovali jsme některé syntaktické rysy textu, které mohou být vnímány jako slohově substandardní, zejména řetězení replik spojkou „a“ („A kněz: ... A on: ...").

\section{Překlad}

Když kněz zaříkával zlého ducha a vyptával se ho na Tělo Kristovo, ten pronesl tato slova: „K té věci, na kterou se mě ptáš, nechovám žádnou náklonnost!“ Pak, složitě zaříkáván a přinucen dalšími modlitbami, zvolal směrem k tomu, jenž se ho tázal: „Chceš, abych ti řekl pravdu? Když muž nebo žena žijí celý život v nepravosti, ale pak Tělo Kristovo s vírou přijmou, jsou zcela vyrváni z mé moci!“ Posléze, zaříkáván stejně jako předtím a dotazován na zpověd’ hříšníků, odpověděl: „Když někdo zhřešil smilstvem, cizoložstvím, vraždou a vůbec všemi neřestmi a později se z toho vyzpovídal, jeho hříchy jsou smyty a já na ně už nedohlédnu.“ Tehdy kněz všechny přítomné důtklivě vybídl ke zpovědi, oni se vyzpovídali ze svých hříchů a zlý duch kvůli tomu křivil tvář a poulil oči, protože trpěl, když se ho kněz dotazoval. A řekl: „Už vůbec nevím, o čem tito lidé mluvili s knězem a kněz s nimi, a dokonce i mé oči z toho osleply." Kněz se ho zeptal: „Co tě oslepilo?“ On na to odpověděl: „Když je mi vyrváno, co bývalo mé, oslepnu.“

Pak ale bez povšimnutí přišli nějací exkomunikovaní. To zlého ducha zatvrdilo a přsestal na další otázky odpovídat.

Kněz ho zaříkával, aby řekl, odkud získal takovou sílu, že se ted' vzpírá. On ale odmítl kněze poslouchat a dál výsměšně mlčel. Tehdy kněz všechny vybídl, aby se pečlivě ujistili, zda nevstoupil někdo, kdo byl exkomunikován. Vzápětí se zjistilo, že mezi př́ítomnými skutečně jsou dva exkomunikovaní. Ti byli náhle tak pohnuti bázní před Bohem, že pokorně prosili kněze o rozhřešení. Když ho obdrželi, znovu předstoupili před zlého ducha, čímž ho uvedli do úzkých. Zahanbeně od nich odvrátil zrak a řekl o nich, že páchnou jako výkaly a že všechno to úsilí, které jim dennodenně věnoval, v tu ránu přišlo vniveč.

40 L. Moulinier-Brogi, „Unterhaltungen mit dem Teufel...“, 548-560. 
Pak byl ke slávě Boží a k posile víry přítomných dotazován na sektu heretiků. Lidi z té sekty označil za své následovníky, přátele a spřízněnce a za nositele své výzbroje. Obratem byl dotázán, co je to za výzbroj. Odpověděl: „Nosí mou výzbroj, protože dobrovolně vykonávají, cokoli si přeji." Nato se ho kněz důsledně a pozorně dotázal, jak ty heretiky odmění a na jaká místa budou kvůli němu posláni. Odpověděl: „Nepřichystám pro ně žádný jiný stolec než náruč svého mistra, v níž budou neustále stoupat a padat ve sloupci roztaveného železa, a pít jim dám všechno tak žhavé nebo naopak tak mrazivé, jak jen budou moci pozřit.“ Kněz řekl: „Proč je pro ně přichystán ten sloupec spíše než jiné tresty?" A on odpověděl: „Protože odpadli od víry do bezvěrectví،“ A kněz se zeptal: ,Jsou ti milejší kataři, nebo židé?“ On odpověděl: „Kataři jsou mi mnohem milejší, protože odpadli od víry, již kdysi přijali, do bezvěrectví.“ Pak se kněz zeptal: „A ti, kteří jim slouží a brání je a stýkají se s nimi, ti jsou také takovými neštastníky?"“ On odpověděl: „Ty, kteří se s nimi vědomě stýkají, stihne stejné neštěstí na duši i na těle.“

Pak zase kněz: „A co se stane s těmi, kteří zemřou nepokřtěni?“ A on: „Ti, kteří prožili své dny a nebyli pokřtěni, jdou se mnou do propasti.“ A kněz: „A kdo jsou ti, kteří prožili své dny?“ A on: „Každý, kdo umírá, završil dny, které mu byly dány.“ A kněz: „Když mnich odloží svůj hábit a bez pokání zemře ve světském stavu, co se s ním stane?“ A on: „Je usazen na stolec mého mistra, prší na něj smola a síra a na hlavu je mu vsazena ohnivá koruna.“ A kněz: „To je ten stolec tak široký, že se na něj všichni takoví vejdou?“ A on: „Všichni takoví, a ještě i mnoho dalších.“ Potom kněz: „Kteří to jsou?“ A on: „Lotři páchající bezpráví, kteří se před smrtí nenapraví, jsou usazeni vedle těch nekajících se mnichů.“Pak se kněz zeptal: „Co se stane se svatokupci, kteři si kupují dary Ducha?“ A on: „Stejnou mzdu jako oni obdrží ten, kdo místo pokory projevuje povýšenost mysli, ${ }^{41}$ to jest pýchu.“ Na to kněz: „A co je to za mzdu?“ A on: „Stihne je trest za pýchu.“ Na to kněz: „A jaký je trest za pýchu?“ A on: „Bude je stíhat trest za trestem.“ A kněz: „A jaké to jsou tresty?“ A on: „Blázne, podívej se na mě! Vždyt já jsem padl do hlubin, protože jsem si osvojil povýšenost mysli, to jest pýchu. Tak i ti, kteři si kupují dary Ducha, jsou vedeni od trestu $\mathrm{k}$ trestu, to znamená z mrazu do žáru a z žáru do mrazu, z výšky padají do hlubiny a jsou vyhazováni zpět do výšky a v dalším trestu znovu padaji.“"Na to kněz: „Těší tě více ti, kteří dary Ducha kupují, nebo prodávají?“ A on: „Ti, kteří prodávají, jdou cestou lakomství. V zá-

41 U slovního spojení alta mens (dosl. vysoká mysl) srov. německé der Hochmut (pýcha, namyšlenost) z hoch (vysoký) + der Mut (kuráž) a zejména synonymní variantu der Übermut (über - nad); též holandské overmoed, dánské overmod či ofermod v raně středověké angličtině. 
sadě mám prodejce i kupce ve stejně oblibě a stejně tvrdě je i trestám. Přece jen jsou mi však prodejci ještě milejší.“

Pak kněz: „A co se stane s jeptiškami, které odloží hábit a nekajícné zemřou ve světském stavu?“ A on: „Jsou poslány do ohnivé pece.“

Pak kněz: „Co řekneš o těch, kteří se účastní turnajů?“ A on: „Ty, kteří byli zabiti v turnaji, aniž se káli, mučím smolou a sírou a na hlavu jim vsazuji ohnivé koruny.“

Pak kněz: „Co se stane s těmi, kteří na svých poddaných násilím vymáhají své nároky?“ A on: „Ty mučím rozžhavenými mincemi a vykonávám na nich i jiné tresty.“

Pak kněz: „Co říkáš o dlouhých pruzích šatů, které za sebou vláčejí ženy a kterým se lidově říká volgenir? ${ }^{\star A 2}$ A on: „Na těch dlouhých šatech si blaženě sedím a hovím, a tak následuji ty ženy ke stolu, na lůžko i tam, kam chodí vykonávat potřebu, a vůbec kamkoliv jdou.“

Dále kněz: „Co víš o katarech?“ A on: „Ty znám dokonale a řekl bych o nich mnohé, kdyby své povinnosti ${ }^{43}$ konali veřejně.“ Na to kněz: „Jaké jsou jejich povinnosti?“ A on: „Nabízejí ostatním lidem pokrm a nápoj své nepravosti.“ Pak kněz: „Co to znamená?“ A on: „Učí lidi nauku své sekty a vzdalují je od katolické víry.“ Pak kněz: „Proč se jim říká kataři?“" A on: „Protože se více než jiným zvířatům podobají kočce a protože kočka je ze všech zvířat nejplnější nečistoty.“ Na to kněz: „A mají ještě něco do činění s kočkou?“ A on: „Mají.“ Co, to už však neřekl. Pak kněz: „Přinášejí ti nějakou obět, že je máš v takové oblibě?"“A on: „Přinášejí mi tu nejdražší obět - zvrhlost incestu.“ Pak kněz: „A proč spolu jejich muži a ženy přebývají v jednom domě?“ A on: „Aby se mohli lépe oddávat neřesti smilstva.“ Pak kněz: „A co se děje s dětmi, které při tom počnou?“ A on: „Zlámou jim vaz.“

Pak kněz: „Je duším zemřelých v neděli dopřán nějaký odpočinek, protože Pán vstal z mrtvých?“ A on: „Od sobotního večera až do prvního kohoutího kokrhání v pondělí si trochu odpočinou.“ Na to kněz: „I ty si někdy můžeš odpočinout od svého utrpení?“ A on: „Ne. Snáším stále to samé s výjimkou toho, že se více raduji, když vykonám něco zlého, a více se soužím, když něco ztratím.“ A kněz: „A co říkáš na svátky světců?” A on: „Čím větší jsou oslavy k uctění Nejvyššího, tím více se soužím.“ Dále kněz: „A co říkáš o varhanách, jejichž hudba se při svátcích světců rozléhá kostelem?“"A on: „Věcí, která těší lidská srdce, se nebojím, hnusí se mi ale slzy těch, kteří hořce pláčou nad svými hříchy.“ A kněz: „Je pravda, že Bůh posílá každému křestanovi dobrého a zlého anděla?" A on:

42 Vlečka, srov. německé folgen - následovat.

43 ,officia“. 
„Každému je poslán dobrý anděl z výšin, aby ho chránil, a špatný od Lucifera, aby na něj dorážel.“

Pak kněz: „Kdo odvádí duši zemřelého křestana k potrestání?“ A on: „Jeho dobrý anděl ji odevzdá zlému andělu pokušiteli a ten ji odvede k potrestání. Nemůže ji ale trýznit víc, než jak dobrý anděl přikáže a jak si zasloužila svými hříchy. Pak ji dobrý anděl odvede očištěnou ke spočinutí.“

Dále kněz: „Odpykávají si duše všechny hříchy zároveň, tedy vraždu společně s cizoložstvím, cizoložství s krádeží a tak dále, nebo každý hřích jednotlivě?" A on: „Lehčí hříchy si odpykávají lehčími tresty, těžší těžšími a každý jednotlivě.“

Pak se kněz zeptal: „A uleví těm duším slavení mší, almužny za zesnulé, ${ }^{44}$ modlitby a další úsilí živých?“ A on: „Toto úsilí právě tak občerství ony duše, jako pokrm občerství hladového, nápoj žíznivého, teplo mrznoucího či chlad spalovaného.“ Na to kněz: „Jak dlouho působí takové občerstvení?“ A on: „Čím více úsilí je pro ně vynaloženo, tím více jsou ty duše občerstveny."

Dále se kněz zeptal: „Co se stane s těmi, kteří nesplní pokání, jež jim bylo uloženo při zpovědi?“ On na to: „Jestliže se vyzpovídali a měli dobrou vůli vykonat pokání, ale zemřeli předtím, než to stihli, ta vůle samotná jim velmi slouží k dobru.“Pak kněz: „A co když někoho děsí vyznat své hříchy, ale ze všech sil se snaží napravit, co spáchal? Pomůže mu to?“ A on: „Trochu ano, ale jen velmi málo.“ Pak kněz: „A co tehdy, když se někdo vyzpovídá a vykoná pokání, které mu kněz uložill?“A on: „Zapomenu všechno, co jsem na něj věděl.“

Pak se kněz zeptal: „Jak se ti líbí spisy téhle staré ženy Hildegardy?“ Tehdy se zahleděl na naši paní Hildegardu a řekl: „Tvé spisy mě těší tak, jako by tebe těšilo, kdyby tě někdo škrtil a dusil!“"Na to kněz: „A to proč?““ A on: „Protože vejdou ve známost k mé potupě.“

Dále kněz: „Jaký děláš rozdíl mezi šedými a černými mnichy?“ A on: „Vpravdě žádný. Jen toho, kdo mi více slouží, mám v o to větší oblibě a toho, kdo službu mně zanedbává, víc nenávidím.“ Dále kněz: „A co si myslíš o mniších, kteří nosí kalhoty a kožešiny, v protikladu k těm, kteří tak nečiní?“"A on: „Ti, kteří nosí kalhoty a kožešiny, mohou stejně oddaně sloužit svému Bohu jako ti, kteří je nenosí. Ti, kteří je nenosí, mi zároveň někdy slouží stejně jako ti, kteří je nosí.“

44 Praxe almužen či darů věnovaných církvi na dobročinné účely, o nichž se věřilo, že pomáhají mrtvým v očistci. Dohledatelné kořeny této praxe sahají k Augustinovi: „Je nepopiratelné, že duším zemřelých se uleví, když jsou za ně díky zbožnosti jejich žijících blízkých přinášeny smírné oběti nebo když se za ně v církvi dávají almužny“ (Augustin, Enchiridion CX: Jean-Paul Migne [ed.], Patrologia Latina XL, Paris: J.-P. Migne 1863, 283). 
Dále kněz: „A co říkáš o těch, kteří slouží mše bez štóly?“ A on: „Takoví mě velmi těší، Pak kněz: „Co říkáš o kněžích, kteří až do smrti žijí s manželkami a nekají se?“ Na to on: „Ti jsou posláni mezi zmije, ${ }^{45}$ tam, kde je plno červů, a tam jsou trýzněni.“ Na to kněz: „A co říkáš o kněžích, kteří slouží mše, i když byli exkomunikováni, nebo jako vrazi, a nekajícní v tom setrvají?" A on: „Ty stihnou ty nejtvrdší z nejtvrdších trestů.“

Dále kněz: „Co říkáš o těch, kteří věští z bylin, ohně, vody, hvězdné oblohy a pomocí dalších umění?“"A on: „Půjdou do ohně, protože to je čarodějnictvii ${ }^{46}$ a každé čarováni ${ }^{47}$ mě těší. Když chce člověk vědět víc, než vědět má, je to čarodějnictví.“

Dále se kněz zeptal: „Co říkáš o těch, kdo přijali řeholní hábit, nosí ho, ač žijí nehodně, ale až do smrti setrvají ve službě Bohu?“ A on: „Pro spásu jejich duše je lepší, když si hábit ponechají, než kdyby ho odložili.“ Dále kněz: „A co o těch, kteři přijali řeholní hábit a pak by ho rádi odložili, kdyby jim to bývalo neuškodilo vzhledem ke světským poctám?" A on: „Jestliže v něm setrvali spíše kvůli světským poctám než ke cti Nejvyššího, málo jim to pomůže.“

Pak se kněz zeptal: „Proč vstupuješ spíše do člověka pokřtěného než nepokřtěného?“ A on: „Protože nepokřtěný už je můj, a tak vstupuji do pokřtěného, abych získal jeho tělo a duši.“

Kněz pokračoval: „Pohané a židé nemají své jednotlivé dobré strážné anděly?“ A on: „Ne. Ale jsou kolem nich zlí andělé.“ Na to kněz: „Když jsou pohané a židé vaši, proč si jejich duše i s těly nevezmete již za života s sebou do pekelných muk?“ A on: „Toho se neodvažujeme, protože mají lidskou podobu. “48 A nic víc na to neodpověděl, protože se nechtěl zmínit o obrazu Božím. Dále se kněz zeptal: „A proč mají hojnost zlata, stř́ibra, dobytka a dalších statků?“ A on: „To všem jim dává d’ábel.“ Na to kněz: „A proč to?“ A on na to: „Blázne! Kdybys měl dítě, které bys miloval, také bys mu snesl vše, co bys mohl.“

Dále kněz: „Očistné tresty jsou ve světě, nebo mimo svět?“ A on: „Jak ve světě, tak mimo svět.“

45 L. Moulinier-Brogiová rekonstruuje př́islušné místo jako „in persinam mittuntur“, tedy ,jsou posláni do persiny“. Slovo persina označuje druh zmije, zde by však syntakticky odkazovalo spíše k určitému místu. Navrhujeme proto čtení „,inter persinas“ - „,mezi zmije".

46 ,maleficium“.

47 Použito něm. slovo zouber, srov. moderní německé der Zauber / pl. die Zauber - kouzla, čáry.

48 ,imaginem hominis habent“. Tzn. i oni jsou, jakožto lidé, stvořeni k obrazu Božímu (srov. Gn 1,26). 
Dále se kněz zeptal: „Nezažene snad slunce temnotu trestů od těch duší, které přebývají ve světě?“ A on: „Blázne! Hmotné slunce neposkytuje mně, který přebývám v temnotách, žádné světlo.“

Na to kněz pokračoval: „Znáš myšlenky lidí?“ A on: „Ne. Jedině když mi někdo z nějakého vlastního nutkání své myšlenky ukáže. A tehdy, jsou-li ty myšlenky zlé, vedu skrze ně toho člověka ke zlu.“ Tehdy se kněz zeptal: „Když nějaký počestný a střídmý člověk pomyslí na nějakou marnivost, ale raději by zemřel, než aby tu marnivost uskutečnil, co na to říkáš?“ A on: „Takové myšlenky nevycházejí ode mě, ale z lidské přirozenosti.“ Na to kněz: „A které myšlenky jsou od tebe?“ A on na to: „Když vidím v nějakém člověku nutkání ke zlu, pobízím skrze to nutkání člověka ke zlu, a tak ho přivedu až k činům. Když někdo myslí na zlo, ale rychle se od těch myšlenek odvrátí k myšlenkám dobrým, odežene mě od sebe. Totiž to nutkání, skrze které poznám myšlenky člověka, je lidské, protože je to vždy lidská přirozenost, co se jako první projeví v člověku, at už vede k jakýmkoliv činům.“

Dále se kněz zeptal: „Proč kněží, kteří se nyní, když máme křest, ožení, páchají těžší hřích než ti, kteří měli manželky před Kristem?“" A on: „Protože to byli pohané a obětovali zvířata. Ted jsou to ale kněží, kteří

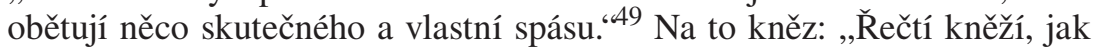
víme, manželky majij.“ A on: „Žádný kněz nemůže právoplatně žít v manželství, aniž by se dopouštěl smilstva.“

Dále se kněz zeptal: „Když jste padli z nebes, padli jste z různých andělských kůrů, nebo z jediného kůru? On na to: „Padli jsme z jediného kůru.“ Kněz: „A kteří z vás padli do pekel a kteří zůstali mimo peklo?“ A on: „Lucifer a knížata temnot padli do pekel. Já však a mně podobní přebýváme mimo peklo mezi lidmi a sepisujeme jejich hříchy.“

Kněz: „Když nějaký člověk odříkává žalmy nebo modlitby a najednou už ani neví, že je říkal, pomůže mu to?“ A on: „Jestliže žalmy a modlitby opakuje, já smažu, co jsem napsal.“ Kněz: „Co říkáš o těch, kteří nedbale odříkávají mnoho žalmů a modliteb, a o těch, kteří jich odříkávají málo?“ A on: „Jeden žalm nebo modlitba pronesená z celého srdce mě tíží víc než mnoho žalmů a modliteb pronášených nedbale.“ Kněz: „Utíkáš před modlitbami pronášenými ze srdce?“ A on: „Utíkám a velmi se jich bojím.“

Kněz se zeptal: „Co říkáš o těch, kteří na kůru vyzpěvují silným hlasem?“ A on: „Jestliže někdo na kůru zvyšuje hlas a pyšně natahuje svůj krk, aby bylo vidět, jaký má krásný hlas, slouží tím mně. Jestliže ale někdo

49 „sacerdotes quod verum est et salutem suam sacrificant“ (ověřeno v reprodukci rukopisu; sacrificant je v rukopise opraveno ze sacrificabunt, Moulinier-Brogiová ve své edici tuto opravu opomíjí). Text může být porušen. Běžná analogie by byla: někdejší kněží obětovali zvířata, nynější obětují Tělo Kristovo (a proto je jejich prohřešek závažnější a zatracují vlastní duši). 
zpívá silným hlasem, aby chválil Nejvyššího, a ne kvůli vlastní slávě, zahání mě, protože to dělá ke chvále Nejvyššího a toho se štítím.“

Kněz: „Nesnášǐš také hromy?“ A on: „Nesnáším.“

Kněz: „Bojíš se kněze víc než jiného člověka?“ A on: „Kdyby neměl kolem krku, to znamená ve své moci, tu stuhu, totiž tu šňůru, ${ }^{50}$ nebál bych se ho o nic víc než jiného člověka. Protože má ale štólu, bojím se ho víc než jiného."

Kněz: „Bojíš se muže víc než ženy?“ A on: „Ne. Ale žena se víc než muž bojí mě, protože je křehčí.“

Kněz: „Je pravda, že jsou duše zemřelých vysvobozeny z trestů díky úsilí živých?“"A on: „Pokud je pro ně vynaloženo správné úsilí, jsou osvobozeny.“

Kněz: „A jsou i hříchy živých smazávány modlitbou a přímluvami a dalším úsilím?“ A on: „Lehčí hříchy jsou smazávány menším úsilím, těžší hříchy vyžadují úsilí větší.“

Kněz: „Znáš myšlenky lidí?““ A on: „Ne, ledaže mi je prozradí chvění jejich těl. Rozpoznám myšlenku, kterou doprovází úmysl uskutečnit ji, a tu zapíšu. Ale myšlenky, které nenásleduje vůle k činu, nezapisuji.“

Kněz: „Zapisuješ všechna slova vyř̌čená nadarmo?“ A on: „Všechna slova vyřčená nadarmo zapisuji.“ Kněz: „A jak to vše zapisuješ?"“ A on: „Nanejvýš dobře si pamatuji vše zlé, co člověk udělal a nečinil pokání. Nemůže to být nijak vymazáno z mé paměti, ledaže je to smyto zpovědí a pokáním.“ Kněz: „A jak se to vše může znovu promítnout v kratičkém okamžiku lidské smrti?" A on: „V jediném okamžiku oči vše znovu promítnou, zlé věci díky mně a mým společníkům, ty dobré však díky andělům, kteří mými společníky nejsou.“

Kněz: „Když ti, kdo přijali svěcení, zanedbávají během dne hodiny určené k službě Bohu a konají své povinnosti mimo stanovený čas, těší tě více, konají-li je před, nebo po stanoveném čase?“ A on: „Když jsou úkony k službě Nejvyššímu vykonávány později, než je stanoveno, mám z toho velkou radost a zapisuji to.“

Kněz: „Když mají mniši v klauzuře dodržovat mlčení, ale nedodržují to, poznamenáváš si to?“ A on: „Každé slovo, které je tam vyřčeno, aniž by bylo nezbytné, si poznamenávám.“

Kněz: „Někteří lidé vyrábějí voskové figurky zpodobňující lidi, které nenávidí. Ty figurky pokřtí a pak spálí. Může to někomu ublížit?“ A on: „My démoni s Božím svolením ubližujeme tomu, kdo je takovou figurkou

50 Použito německé snur; srov. moderní něm. die Schnur - šňůra, stuha. 
zpodobněn, aby ten, kdo figurku vyrobil, ještě více věřil v kouzla. Nemůžeme tím ale obět usmrtit.“51

Kněz: „Když někdo převezme pokání za zemřelého vraha, pomůže to tomu zemřelému?“"A on: ,Trochu mu to pomůže, ale mnohem lepší by pro toho mrtvého bylo, kdyby se býval kál sám.“

Kněz: „Co jsou zač Witdechen?“52 A on: „To jsou démoni, kteří se dovedou měnit $\mathrm{v}$ mužíčky, kdykoliv jen chtějí, aby oklamali ty, kteří v ně věří.“ Kněz: „A odkud jsou ty poklady a další věci, které dávají těm, kdo v ně věří?" A on: „Jsou od d'ábla a slouží k oklamání lidí،“

Kněz: „Co je zač ta, které se říká Holda a která se za nocí zjevuje lidem jakoby ve velké slávě?“ On: „To jsou všechno démoni, kteří tak klamou lidi.“ Kněz: „A jak se to stane, že někteří po tom setkání oslepnou a ochrnou?“ A on: „Protože v nás věří, takto je poznačíme, aby v nás věřili ještě víc a abychom díky tomu mohli podvádět další lidi.“

Kněz: „Když kněz udělí rozhřešení zesnulému exkomunikovanému, prospěje to jeho duši?“ A on: „Jak by mohlo pomoct trestané duši, že chce kněz udělit rozhřešení rozkládajícímu se tělu? Nijak. Ten, kdo je svou vinou na základě spravedlivého rozsudku exkomunikován a pyšně a zatvrzele se staví na odpor a netouží po rozhřešení a v tom stavu zemře, je můj.“

Kněz: „Co říkáš na to, když je někdo exkomunikován kvůli něčí zášti nebo jinak nespravedlivě, ačkoliv je bez viny, a zemře v tom stavu?" A on: „Za takovou exkomunikaci následují lehké tresty. Nepropadne mi však do zatracení; naopak ten, kdo ho exkomunikoval, je větším viníkem.“

Kněz se zeptal: „A co ř́káš na ty, kteří jsou automaticky exkomunikováni pro menší provinění, tř̌eba kvůli senu, ovoci nebo hroznům?"53 On na to: „Po smrti je čekají tresty, i když lehké. Zatracení ale nejsou.“

51 Na tomto místě je v rukopise zapsáno a poté přeškrtnutím zrušeno ,Et que pena illis debetur? Et ille“" (,A jaký čeká tyto lidi trest? On na to:“). Moulinier-Brogiová zrušený text pojímá do své edice. Do českého překladu jej nezařazujeme.

52 Nejspíš skřítci, permoníci. Etymologicky souvisí také s některými dialektálními označeními malých dětí. Srov. německé der Wicht - skřítek a nářeční das Wicht - dětátko (hl. dolní Porýní). Tato etymologická příbuznost se promítá i do textu: Witdechen mají podobu malých dětí a dávají lidem poklady.

53 Nejspíš je zde míněno odpírání prvotin a desátků z úrody, které se měly odevzdávat církvi. To je stiženo exkomunikací podle Decreta Gratiani: „Každá desetina toho, co vzejde ze země, klasy, stejně jako plody stromů, patř́ Pánu ... protože se však najdou mnozí, kteři desátky dávat odmítají, ustanovujeme, aby byli podle př́ikazu našeho Pána napomenuti jednou, podruhé, potřetí. Jestliže se nenapraví, at na ně padnou okovy anathematu“" (E. Friedberg [ed.], Decretum magistri Gratiani..., 3.16.7). Připadala by v úvahu také krádež úrody. Za tu následovaly ve Svaté říši římské tvrdé světské tresty. Srov. tzv. Saské zrcadlo, sbírku původně zvykového práva, kodifikovanou na začátku 13. století: „Kdo v noci krade úrodu, toho čeká šibenice, kdo krade ve dne, bude ho to stát krk" (Sachsenspiegel II.39.1: Karl August Eckhardt [ed.], Sachsenspiegel Landrecht, Göttingen - Berlin - Frankfurt: Musterschmidt 1955, 163). Není však zřejmé, proč by měla taková krádež podléhat církevní exkomunikaci. 
[Kněz:] „Co říkáš na to, když se dva pontifikové navzájem exkomunikují i se všemi stoupenci protivníka?“ A on: „Ty, kteří jsou exkomunikováni tímto zpo̊sobem, čekají lehké tresty. Mému mistru ale nepropadnou, protože je to chyba těch dvou. Mému mistru však propadnou ti, kteří onu věc způsobili.“ 54

Kněz: „Když člověk zemře, které hříchy si bude muset odpykat jako první?“" A on: „Nejprve hříchy, které spáchal v dětství, a pak postupně všechny hříchy, které spáchal až do své smrti a nekál se z nich.“

Kněz se zeptal: „Když je duše vysvobozena ze svých trestů, přecházejí tresty té duše na další duši?“ On odpověděl: „Když je duše vysvobozena ze svých trestů, trest té duše končí hned poté, co je vysvobozena, a nepřechází na další duši, protože s odchodem té duše zaniká. Každá duše totiž, než opustí tělo, si sama svými odpornými a zlými skutky připravuje rozličné tresty, ${ }^{55}$ které ji uchvátí, jakmile opustí tělo.“

Kněz: „Pomáhají ochranná znamení ${ }^{56}$ svým nositelům?“ A on: „Vůbec ne. Naopak ti, kteří je nosí, slouží mně a mým společníkům.“ Kněz: „A odkud taková znamení pocházejí?"“ A on: „Od d’ábla.“

Kněz: „Jsou d’áblové také silnější a slabší, stejně jako jsou silnější a slabší lidé?“" A on: „Jsou.“

Kněz: „Je mezi démony příměří, nebo různice?“ A on: „Když ztratí někoho, koho předtím získali, je mezi nimi velká pře a různice, perou se a navzájem se drásají a koušou. Když jim ale někdo vinou svého vlastního rozhodnutí propadne, zase se usmíří a radují se.“

54 Úryvek odkazuje k př́ipadům církevního schizmatu, kdy se papežové exkomunikovali nejen navzájem, ale i včetně všech podporovatelů a př́íznivců protistrany. Konkrétně se může jednat o odkaz k událostem let 1159-1180, kdy Alexandr III., posléze uznaný za právoplatného pontifika, sváděl boj s nárokovateli papežského stolce, podporovanými stranou císaře Fridricha I. Barbarossy. Postupně jimi byli Viktor IV., Paschal III., Kalixt III. a (vzdoropapež) Inocenc III. Viz Christine Laudage, Kampf um der Stuhl Petri: Die Geschichte der Gegenpäpste, Freiburg im Breisgau - Wien: Herder 2012, 112-130. Je-li tomu tak, pak se jedná o indicii ve prospěch datace pramene či této jeho části do pozdního 12. století, kdy bylo dotyčné papežské schizma stále diskutovaným tématem.

55 Těžko čitelné místo, porušené otřením inkoustu, přepisuje Moulinier-Brogiová jako „sibi venas fecit“ (vena - primárně „,̌íla“, také „,proud“, přeneseně i „předpoklad“"). Věta by pak nejspíš dávala smysl jako „každá duše ... si připravila vlastní cestu, než opustila tělo“. Nepovažujeme to však za př́iliš přesvědčivé a kloníme se k rekonstrukci slova jako varias s vypuštěným následným penas: „Každá duše ... si připravila své vlastní rozličné (tresty). “Čtení varias, nejen venas, je zcela myslitelné i s přihlédnutím $\mathrm{k}$ tomu, co se ze slova v rukopise zachovalo.

56 Použito lat. caracteres - doslova ,známky, značky“; zde jistě označují nějakou formu ochranných znamení, amuletů, možná i značek na těle. 
Kněz: „A co je zač to, čemu lidé říkají aneganc, ${ }^{57}$ totiž to, když podle běhu zvířat předvídají, zda budou mít štěstí, nebo smůlu?“ A on: „To je čarodějnictví, které je od dábla, který tak lidi odvádí od víry, a proto zařídí, že ty lidi skutečně často potká štěstí nebo smůla tak, jak tomu věří.“

Kněz: „Trpí trestané duše hladem a žízní?““ A on: „Některé ano.“ Kněz: „Uleví jim almužny za mrtvé?“ A on: „Tak jako chléb uleví hladovějícímu a nápoj žíznivému, tak i jim uleví almužny.“ Kněz: „A co když někdo na almužny nemá, jako mniši, ale odříkává za své drahé zesnulé žalmy? I těm se uleví od hladu a žízně?“" A on: „Ano, uleví.“

Kněz: „Co říkáš o mniších, kteří tě těší?“A on: „Takového mnicha mám raději než klerika, klerika raději než laika a jeptišku raději než laičku, kdykoli se vzdávají zasvěceného života, protože porušují slib, který dali.“

Kněz: „Rozzlobí tě víc zpověd’ učiněná před vlastním pastýřem, nebo před cizím knězem?“ A on: „Zpověd' vlastnímu knězi ${ }^{58}$ mě rozzlobí víc než zpověd” cizímu knězi.“”

Kněz: „Když kataři zlámou dětem vazy, co dělají s mrtvolkami?“ A on: „Spálí je na popel.“ Kněz: „A co potom dělají s tím popelem?“ A on: „Rozprašují ho na tajných místech a na nich pak působením dábelských svodů nacházejí vše, po čem touží, tedy zlato, stříbro, chleba, ryby, víno a další věci, které tam dávají mí společníci, aby je ještě více podvedli. Oni si totiž myslí, že ty věci vznikají z toho popela nebo z nějakého jiného semene.“ Kněz: „Co dělají kataři, když políbí kočku na řit?“ A on: „Oddávají se smilstvu.“ Kněz: „A co dělají s dětmi, které při tom počnou?““ A on: „Zlámou jim vazy a spálí je na popel. Jednoho muže a jednu ženu ale pokaždé ušetří. Muže, když dospěje, mají za proroka a následují jeho učení. Ženu pak společně sdílí a děti, které se jí narodí, mají za světce a spálí je na popel, jak jsem už řekl.“

Kněz: „Kam odvádíš pohany, židy a všechny nepokřtěné, když zemřou?“ A on: „Do jámy Tartaru, to jest do pekla.“

Kněz: „Na jaké místo líbají kataři kočku?“ A on: „Na pozadí, na to místo, které mají ženy.“ Kněz: „Jak velká je ta kočka a jakou má barvu?“ A on: „Je velká jako velký pes a z obou boků jí vyráží ptačí peří a barvu má bílou.“ Kněz: „A za co tu kočku považujî?“A on: „Někteří ji považují za dábla, ale následují ji, protože jim dává vše, co chtějí. Někteří ji ale považují za dobrého anděla, a tak jsou podvedeni.“

57 Složenina ze středověkého německého ane - před, časově předcházející (srov. moderní ahnen - předvídat nebo der Ahn - předek) + ganc - pohyb, chůze (srov. moderní der Gang - chůze). Srov. i pozdější der Angang, hovorově též označující předvídání budoucnosti, jinak synonymní s der Anfang - začátek.

58 Ve smyslu kněze farnosti, do níž zpovídající se člověk patří. 
Kněz: „Těší tě víc, když si nějaký mnich soukromě odříkává modlitbu po kompletáři, ${ }^{59}$ nebo když ji odříká ve stejný čas, ale sedí na svém lůžku?“ A on: „Když mnich po kompletáři odříkává modlitbu v oratoriu, těší mě to víc, protože je to projev neposlušnosti.“

Když jsme se usadili kolem trpící, démon náhle začal křičet: „Ach, ach, ach! Můj společník jménem Suslufult a Snelhart ${ }^{60}$ právě přichází a říká, že mě má za hlupáka, protože on, tajný mistr katarů, právě předal svému otci velmi milou zprávu, že kataři v Mohuči usmrtili a na popel spálili dítě, za což byl přijat naším knížetem Luciferem s velkými poctami a nesmírnou radostí a dere se na moje místo!“ Na to my: „A kde je?“ A on: „Je tady hned vedle!“ A křičel: „Přísahám na svoje oči, že tvoje oči a tvoje stará tlama dostanou za tuhle drzost co proto! Já těším svého mistra víc než ty a k tvé potupě toho řeknu ještě víc o katarech, jejichž jsi mistrem!“ A tak při exorcismu pověděl o všech těch ohavnostech sekty katarů, jak již bylo řečeno.

Kněz: „Pobýval před Kristovým umučením Lucifer na světě a potuloval se jím?“ A on: „Potuloval.“ Kněz: „Po umučení Krista už se světem nepotuluje?“ A on: „Od té doby přebývá v Tartaru, tedy ve svém království, protože se bojí, aby ho o něj někdo nepřipravil.“"

Kněz: „Kam jsou odváděny duše těch, kteří se oběsí na oprátce, upálí v peci nebo utopí ve vodě a udělají to kvůli svým hříchům a kvůli Bohu?“ A on: „Mí druhové je odvádějí do pekelných hlubin.“ Kněz: „A proč se tak děje, i když to dělají pro Boha?““ A on: „To my je přivádíme k tomu bludu, aby si mysleli, že tím potěší Boha. Ve skutečnosti tím však slouží nám.“

Kněz: „Ponoukáš lidi k hříchům?“ A on: „Snadno dokážu přimět křestany, aby někoho zneuctili, zabili, oloupili nebo s někým zcizoložili a podobně, když vidím, že k tomu už tíhnou. Když na moje ponoukání přistoupí, rychle je přiměji $\mathrm{k}$ tomu, aby ten hřích spáchali. Když na něj ale nepřistoupí, uteču od nich.“ Kněz: „A nadřeš se víc, abys přesvědčil osoby duchovní, nebo světské?“" A on: „U duchovních se nadřu, protože ty mi vzdoruji."“

A když se jakýsi rytíř vyzpovídal knězi ze svých hříchů, zlý duch zakřičel: „Ach, ach, mí druhové od něj utíkají v takovém počtu, jako když sněží z mraků!“‘

59 Závěrečná večerní modlitba liturgie hodinek.

60 Obě jména asi nesou podobný, až shodný význam: Suslufult snad etymologicky souvisí s der Schuss - střela + laufen - běžet. Snelhart se pak zdá souviset se schnell - rychlý, rychle + hart - tvrdý, zde spíše v přeneseném významu „nezdolný, nedosažitelný“; srov. lat. arduus - nezdolný, nesnadný, obtížně přístupný. Obě tak nejspíš odkazují $\mathrm{k}$ bytosti charakteristické mimořádně vysokou rychlostí pohybu. Tato etymologická hypotéza souzní i s rolí dotyčného démona jako posla, který nosí zprávy. 
Kněz: „Odvážíš se vyslovit Boží jméno?“ A on: „Odvážím, když chci.“ A rozzlobeně dodal: „Je Bůh.“ Kněz: „Koho nazýváš Bohem?“ A on: „Boha na nebesích.“ Kněz: „Čemu říkáš nebe?“ A on nahněvaně: „Nebe je tam, kde je Boží trůn.“ Kněz: „A čemu říkáš trůn?“ A on nahněvaně: „Trůn říkám tomu, před čím stojí Michael.“ A rozzuřeně dodal: „Odvážím se jmenovat i Boha Ježíše, syna Mariina.“

Kněz: „Zmocníš se duše muže, který opustil svou právoplatnou manželku a vzal si jinou, nebo manželky, která opustila svého právoplatného manžela a vzala si jiného, a tak bez pokání umírají?“ A on: „Pokud se před smrtí nekáli, jsou moji a dočkají se náležité odměny.“

Kněz: „Kdy líbají kataři kočku? Mají pro to stanovený čas, nebo ne?“ A on: „Dělají to vždy, když je mistr katarů svolá, a to je kdykoliv, kdy se mu zlíbí, aby se k tomu konání sešli.“”

Kněz: „Znají démoni budoucnost?“ A on: „Ani Lucifer, ani jiní démoni neznají budoucnost, ale dokáží ji odhadnout - podle teploty vzduchu, podle toho, co si lidé šeptají, nebo podle jejich projevů.“61

Kněz: „Proč dávní světci, jako Martin, Remigius či Benedikt, vyháněli démony z posedlých těl snadno, ale dnes je to velmi náročné?" A on: „Takoví jako oni dnes už nejsou k nalezení. Oni totiž v prostotě sloužili Bohu, kdežto dnes jsou lidé stiženi obojakostí srdce. ${ }^{62}$ Proto se my démoni více vzpíráme, zatímco tehdy jsme museli být poslušnější, protože tehdejší světci byli také poslušni Boha.“ Kněz: „Jsou i dnes nějací svatí?““ A on: „Rozhodně ano.“

Kněz: „Je ti milejší vražda, cizoložství, nebo smilstvo?“ A on: „Vražda je mi z toho nejmilejší.“ Kněz: „Je ti milejší znásilnění, ${ }^{63}$ nebo krádež?"“ A on: „Krádež je mi milejší.“ Kněz: „A proč?““ A on: „Protože já sám jsem zloděj a vše dělám pokradmu.“

Kněz: „Bereš na sebe někdy jinou podobu?“ A on: „Když chci, měním se v anděla světla ${ }^{64}$ a také v krkavce, myš, mouchu a další tvory.“”

Když jednoho dne přišlo mnoho žen i mužů, aby byli svědky té podívané, démon byl silnější než obvykle. Kněz: „Odkud jsi získal takovou sílu?“ A on: „Přŕsahám při Nejvyšším, že to, co ti ted’ řeknu, je pravda. Když démon posedne nějakého člověka, napodobuje to, $v$ čem je ten člověk sám

61 Odpověd’ vychází z tradice Augustinova textu $O$ věštění z démonů (De divinatione daemonum). Augustin v něm píše, že démoni sice neznají budoucnost (tu zná jen Bůh), avšak díky svým zkušenostem, rychlému pohybu svých éterických těl a díky svým rozumovým schopnostem dokáží shromáždit velké množství informací a z nich mnohdy správně vyvodit, co se stane v budoucnu (Augustin, De divinatione daemonum: J.-P. Migne [ed.], Patrologia Latina XL..., 584-585).

62 Srov. Sír 1,28: „Nevzpírej se bázni před Hospodinem, ani k němu nepřistupuj s obojakým srdcem."

63 „rapina“; též loupež, loupežné přepadení.

64 Srov. $2 K 11,14$. 
zdatný. Když byl nějaký člověk z nějakého důvodu veselý, démon si přisvojí jeho veselí, když smutný, tak i démon si osvojí jeho smutek. Nebo když se $\mathrm{v}$ někom vařila krev hněvem, i démon v něm dává najevo hněv. A protože jednu z příchozích žen ovládá v mysli hněv, získal jsem svou sílu.“

Podobně mluvil o dalších věcech. Paní Hildegarda řekla: „Tu nemoc, která mě postihla, na mě vdechli tví druhové?“ A on: „Vdechli jsme ji na tebe, a hlavně démon, kterému se říká Nochdols.“" ${ }^{65}$ A ona: „Vidím ústa Luciferova, která chrlí olovo a zalívají tě do něj a už ti neposkytnou žádnou pomoc!“ A on: „Ach a běda tobě, že máš takové oči!“ A paní Hildegarda: „Vidím, jak tví druhové vyjí zoufalstvím, protože si mysleli, že skrze tebe dosáhnou slávy, ted' jsou však uvedeni ve zmatek, protože selháváš ve svém snažení!“‘ A on: „Ach, ach, ach a běda nám, protože odhaluješ všechny naše úklady a úradky a my jsme z toho tolik zmatení. Jak bychom jen posílili, kdybychom tebe samotnou dokázali přemoci!“" A Hildegarda: „Vidím oheň, který sama svatost přidělila tobě, neštastníku, a v jehož žáru opustíš schránku, kterou jsi posedl!“ A on: „Odhaluješ všechna pokušení, která osnujeme, a mí společníci, když se sešli, aby shromáždili své úlovky, mluví o tom, že se nemohou skrýt před tvým pohledem, protože zmař́řs každý jejich úklad, a vznikla mezi nimi proto velká pře. Takové oči máš. Kéž by tvé oči osleply! Zrak žádného jiného člověka nám nikdy nenadělal tolik potíží. Vždyt vidíš až na dno pekla!““

Démon v další ženě řekl, že ho obzvlášt těší bubnováníi6 a povykování při hrách. Právě takovými hlasy se totiž svolávají i zlí duchové. Také je jim milejší křepčení než důstojná chůze v průvodu.

A řekl: „Jestliže někdo něco dá do opatrování a zemře a ten, kdo tu věc opatroval, ji nevrátí dědicům, hřeší. Nebo pokud ten člověk dědice nemá, má ji věnovat za duši zesnulého.“

A dále řekl: „Jestliže je někdo na shromáždění veřejně nařčen z nějakého zločinu a je mu za ten zločin uložen trest, je pro něj dobré, aby se posléze $\mathrm{z}$ toho zločinu $\mathrm{v}$ tajnosti vyzpovídal knězi, protože před shromážděním člověk obvykle nechce ten zločin odčinit ze své vůle, ale z donucení.“

A dodal: „Když se někdo jednou vyzpovídal z nějakého hříchu a vykonal za něj uložené pokání, není nutné, aby se z něj zpovídal znovu. Jestliže

65 Snad nach - poté + středověké dolnoněmecké dolen - přetrvávat; případně etymologická souvislost s moderním holandským dollen (toulat se, bloumat). V obou případech by nach/noch + dol(l)en mohlo původně označovat bludnou navrátivší se duši, revenanta (srov. moderní německé der Wiederganger z wieder - znovu + gehen - chodit), a druhotně se stát jménem démona.

66 Slovo, které Moulinier-Brogiová přepisuje jako crumina (snad var. crumena - měšec), v daném kontextu nedává smysl. Vzhledem ke kontextu je pravděpodobnější rekonstrukce trumma, tedy latinizovaná podoba Trumme - ve stř̌ední dolní němčině „buben“. Nahlédnutí do rukopisu tuto domněnku potvrzuje: stojí v něm skutečně truma s obecným zkracovacím znaménkem nad $u$, a je tedy třeba číst trumma. 
se ale poté znovu vyzpovídá, je tím dokonaleji od toho hříchu očištěn. Jestliže znovu spáchá hřích, z něhož se už jednou vyzpovídal, má se z něj vyzpovídat znovu a napravit se. Jestliže bylo někomu uloženo pokání, které není s to vykonat, at se $\mathrm{z}$ téhož hříchu vyzpovídá stejnému nebo jinému knězi, svěří se mu, že nezvládne vykonat uložené pokání, a poprosí, aby mu bylo uloženo nějaké pokání lehčí, které pak splní. Bůh totiž na nesplnitelném pokání nelpí, nýbrž je ohledně něj shovívavý. Když někdo při zpovědi knězi řekne ,beru na sebe toto pokání‘ a představí to pokání knězi a kněz mu ho skutečně uloží, musí kajícník to pokání také pečlivě vykonat tak, jak sám navrhl. Zpověd, kterou člověk učinil sám od sebe, je lepší a užitečnější než ta, kterou mu kněz předříkal.“

Kněz: ,Jestliže někdo získal kostel nebo opatství nebo jiný duchovní dar skrze simonii, vyzpovídá se knězi a zřekne se toho statku, ale kněz mu jej svěří nazpět, aby v čistotě sloužil Bohu, at jej s klidem přijme. Jestliže ale nekajícný zemře jako simonista, bude navždy zatracen.“

A řekl, že k nápravě většiny hříšných slov stačí domluva. A že litanie, to jest recitování jmen světců, pomáhají lidem významně a víc než jiné modlitby, protože jsou v nich vzýváni světci se svými zásluhami. A jestliže někdo páchá cizoložství s vdanou ženou a manžel té ženy zemře a on ji pojme za zákonnou manželku, tak pokud se neodloučí a bez pokání zemřou $\mathrm{v}$ tom stavu, budou zatraceni. Jestliže se však vyzpovídají knězi a ten jim po odpuštění hříchů dovolí dál spolu žít, budou muset do konce světa snášet tresty. Pak je ale Kristus spasí.

Řekl také, že Michael, který v první bitvě bojoval s drakem, je rovněž předurčen bojovat se zlými duchy o duše lidí a že je knížetem duší. Když lidé umírají, září jeho jas a on na váze váží vše dobré, co křestan vykonal, a dábel naproti němu váží všechno zlé. A [Michael] propůjčuje svůj jas andělovi, jemuž byl člověk svěren, a anděl duši odvádí na místa trestů, kde ji předá zlým knížatům, aby byla očištěna. A tam je s ní jas prvního z andělů, dokud se neočistí, at už setrvá v očištování po dlouhou dobu, nebo jen krátce. Řekl také, že nejprve se člověk očištuje od těžkých hříchů a až potom od lehčích.

A řekl: „Automatická exkomunikace kvůli obilí, úrodě, ovoci, ořechům a podobným věcem vede $\mathrm{k}$ zatracení toho, kdo věděl, co se má, a nedbal o to. Toho, kdo o tom nevěděl, se netýká. A jestliže tak jednali služebníci na rozkaz svých pánů, budou očištováním trpět méně, zatímco jejich páni jsou hlavními viníky.“67

67 Znovu nejspíš míněno odpírání prvotin a desátků, viz výše. Oba úryvky jsou v napětí - v prvním se uvádí, že tato automatická exkomunikace kvůli prvotinám k zatracení nevede. 
Řekl také: „Bůh těm, kteři se často prohlížejí v zrcadle, říká: ,Jsi tak namyšlený jako ten, kdo se jako první takto prohlížel, a proto s ním budeš i př́ebývat."“

Také řekl: „Svatým, jež lidé ... [nečitelné] ${ }^{68} \ldots$ pamatují, budou jim v onom životě útěchou. ‘69

Také řekl: „Protože démonům se nedostává Boží lásky, která je vroucí ... [nečitelné] ... v pekle, kde Boží láska není.“

Dále řekl: „Bůh vždycky vidí rány na těle křestana, který byl bezdůvodně zabit. Kdo nenávidí svého bližního, bude trestán v ohni. Kdo je chlípný a marnivý, bude trestán červy. Kdo závidí bližnímu jeho statky, bude trestán mrazem.“

Řekl také: „Jestliže někdo žije v klauzuře nedobrovolně a stále zamýšlí utéct $^{70}$ a s tímto úmyslem i zemře, bude trestán smolou a sírou.“

Řekl: „Vrah nenahlédne tvář Otce v takové plnosti jako jiná duše, protože zahubil Božího tvora.“

Řekl: „Cizoložník bude trestán větším žárem než vrah, protože cizoložník jedná skrytě, bez bázně a bez pokání, zatímco vrah hřeší veřejně a bojí se, veřejně se kaje a prosí o pomoc, ${ }^{71}$ což cizoložník nečiní.“72

Řekl: „Mniši, kteři se obrátili ke světu a zemřeli v něm, ${ }^{73}$ budou trestáni více než židé a pohané a budou pít nápoj Luciferův.“

Také řekl: „Jestliže někdo někoho zabil a byli u toho i další lidé, kteří se na vraždě nepodíleli, ale měli to v úmyslu, jsou ti lidé stejně tak vinni

68 Nabízí se čtení ,in terra“, tedy „,na zemi“. Pak by nejspíš tvar Sanctis (dativ či ablativ plurálu) představoval gramatickou chybu v rukopisu a gramaticky korektní tvar by zněl Sancti (nominativ plurálu). Srov. ovšem poznámku 69.

69 Moulinier-Brogiová nabízí částečný přepis věty: „Sanctis quos homines [...] in memoria sua habent in illa vita, eis consolationes exibent." Vzhledem k tomu, že podle rozsahu poškozeného místa je nejspíš vynecháno jen jedno slovo, je takové znění gramaticky neohrabané z hlediska deklinací (viz poznámku 68). Při prozkoumání reprodukce rukopisu se nabízí alternativní přepis ,Sanctis quibusque homines [culturam] in memoria sua habent, in illa vita eis consolationes exibent.“ Tedy, „At lidé chovají $\mathrm{v}$ úctě kterékoliv svaté, [tito] jim budou v onom životě (tj. při pobytu v očistci) poskytovat útěchu." Věta by pak dávala smysl jako věroučné upozornění, že všichni svatí mají stejnou moc coby přímluvci u Boha, a nelze říkat, že jeden světec pomáhá více a jiný méně. Vzhledem k míře poškození textu ale nelze správnost takového přepisu s určitostí potvrdit.

70 Editorka přečetla „Si quis in claustro invitus est et semper voluntatem ... (loc. corr.) endi habet". Kvalitní reprodukce rukopisu umožňuje přečíst porušené místo se setřeným inkoustem jako fugiendi.

71 Nejspíš míněn dopadený a odsouzený vrah, který před popravou prosí o svátostné zaopatření.

72 Výše naopak démon uvádí, že má vraždu ještě raději než cizoložství či smilstvo. Podobné rozpory a opakující se témata snad mohou ukazovat na kompilaci z více textů.

73 Tzn. odložili mnišský hábit a zemřeli ve světském stavu. 
smrtí toho člověka. Jestliže ale neměli v úmyslu se na vraždě podílet, nejsou jeho smrtí vinni."

Také řekl: „Jestliže někdo někoho zabil a zemřel, aniž se kál, a někdo další za něj podstoupí zástupné pokání, jeho duši trochu ulehčí od trestu a náporu démonů. Jestliže pro něj někdo podstoupí zástupné pokání a obdrží za to peníze, jak to často dělají kněží a mniši, hřeší, zatímco ten, kdo peníze dává, je prost hříchu.“

Řekl: „,Každý se má zpovídat svému vlastnímu knězi, ${ }^{74}$ jestliže ten je ale hloupý a nedokáže kajícníkovi pomoci, at kajícník hledá pomoc jinde.“

Také řekl: „Jestliže někdo slíbí, že se vydá na pout k Božímu hrobu, $\mathrm{k}$ svatému Jakubu ${ }^{75}$ nebo jinam, a nahradí tu pout almužnou, ${ }^{76}$ má rozhřešení a d'ábel je rozzlobenější, než kdyby tu pout vykonal, protože by na ni býval šel pro marnou slávu nebo z jiného marnivého důvodu, a ne $\mathrm{z}$ bázně před Bohem.“

Řekl též: „Půst těší Boha víc než bičování se, protože půst vede k umrtvování těla, bič však nikoliv.“

74 Tzn. svému farnímu knězi; viz i výše.

75 Tzn. do Santiaga de Compostela.

76 Běžná praxe, kdy kajícník místo nákladů, které by musel vynaložit na pout', věnoval dar církvi, nemohl-li z nějakého praktického důvodu pout vykonat. 


\section{SUMMARY}

The Demon as the Mirror of Truth: Theology, Moral Instruction, and Heresy in a Rhineland Description of Exorcism (ca. 1200)

This article provides the first Czech translation, with introduction and notes, of the description of an exorcism ritual included in ms. 9 from the Abbey of St. Peter and Paul in Termonde (Dendermonde), well-known to scholars of Hildegard of Bingen, whom the text mentions as being present at the ritual. The article discusses the origin of the text, arguing for its later redaction than in the 1170s, the decade suggested by Laurence Moulinier-Brogi, yet still earlier than about 1230, the approximate year proposed by Uwe Brunn. We assume the very end of the $12^{\text {th }}$ century to be the most probable date, while pointing out the need for further research, which should shed light on the gradual genesis of the source in the context of early hagiographic writings about Hildegard of Bingen.

We further discuss some of the significant topics of the source, chiefly the demonization of heretical groups in the lower Rhineland as well as the condemnation of sorcery and superstitious beliefs. In particular, we point out the absence of any echoes of the Cathar ritual of consolamentum from passages mentioning the Cathar heresy. This leads us to the hypothesis that the text echoes specific heterodox doctrines and practices of late $12^{\text {th }}$-century lower Rhineland, with no direct connection to the dualist heterodox movement of Languedoc and Lombardy, although both milieus were labelled as cathari. Regarding the condemnation of sorcery and superstition, we briefly discuss the role of the mythical female figure called Holda in high medieval folklore. The second part of the article consists of the translation of the source. The translated description of an exorcism brings important testimony about the morally educative efforts and concerns of the Church administration in the lower Rhineland at the turn of the $13^{\text {th }}$ century. Our translation is based on the edition by Laurence Moulinier-Brogi with some suggestions and corrections.

Keywords: Dendermonde Codex 9; Hildegard of Bingen; exorcism; demons; sins; Christian ethics; Christian eschatology; Cathar heresy.

Department for the Study of Religions

FRANTIŠEK NOVOTNÝ

Masaryk University

Faculty of Arts

Arna Nováka 1

60200 Brno

Czech Republic

Department for the Study of Religions

DAVID ZBÍRAL

Masaryk University

Faculty of Arts

frantisek.novotny@mail.muni.cz

Arna Nováka 1

60200 Brno

Czech Republic

david.zbiral@mail.muni.cz 